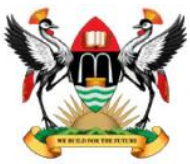

East African School of Higher Education Studies \& Developmen
Makerere Journal of Higher Education

ISSN: 1816-6822; 7 (2) (2015) 117 - 132

DOI: http://dx.doi.org/10.4314/majohe.v7i2.8

(C) The Author(s) 2015

Reprints \& permission: EASHESD

http://ajol.info/majohe

\title{
Implications of Enhancing Access to Higher Education for Quality Assurance: the Phenomenon of Study Centres of Kenyan Universities
}

\author{
Florence M. Itegi ${ }^{1}$ \\ ${ }^{1}$ Kenyatta University [*E-mail: muitegi.ku.ac@gmail.com]
}

\begin{abstract}
This study sought to accomplish three objectives: to examine the expansion of access to university education in Kenya; to examine the implications of expansion of access for the quality of university education; and to develop a model showing interrelationships between the expansion of access and quality assurance, based on lessons learnt from study centres established by both public and private universities in the country. The study was based on literature review, which was augmented by key informant interviews, focus group discussions and observation. It revealed that the study centres marked a great stride in opening access to higher education, especially for the working class, and in increasing the number of graduates from secondary schools, provided facilities for face to face tuition and a range of benefits to their host communities. However, the centres also face difficulties in relation to physical structures, learning resources, staffing and retention of students.
\end{abstract}

Keywords: Massification; Study centres; Quality assurance.

\section{$1 \quad$ Introduction}

The world Tertiary Gross Enrolment was about 24\% in 2005. However, participation substantially varied from region to region, ranging from $5 \%$ in sub -Saharan Africa to $75 \%$ in North America and Europe. Bahemuka and Brockington (2001) noted that approximately 30,000 Kenyan students were studying abroad with $60 \%$ in North America while $24 \%$ were in India, the remaining were mostly in Britain and other countries of which $90 \%$ were privately sponsored, while $10 \%$ received government scholarships. Total amount of money spent annually by Kenyans on university education abroad was noted to be a colossal amount. Despite the continuing expansion of tertiary 
education world wide a relatively small share of the relevant age group has access to this level of education in developing countries. In Kenya the problem of access to higher education was compounded by the Free Primary Education in 2003 and the Free Day Secondary in with subsidized tuition programme that saw more candidates seeking higher education than ever before.

To enhance access to higher education universities in Kenya opened up centres to co-ordinate open and distance learning in various parts of the country in the 1990s but the response was not significant in helping to ease congestion in the main campuses, this was due to the fact that most learners in developing countries still believed in traditional methods of education where face- to- face mode is prevalent. This led to accelerated opening of study centres as satellite campuses in main urban centres in colleges, schools, church buildings or other establishments whenever concentration of students in those areas justify. However, the number of students in Open and Distance learning centres kept dwindling as student took long to complete their courses while others completely dropped out. This was followed by opening of satellite campuses by various universities in Kenya where face to face mode was initiated. With the rapid establishment of learning centres off campuses, the concern about the quality of higher education has been on the rise among various stakeholders yet no study has been carried out on the status and scope of activities in these centres. This notwithstanding it is not clear what respective universities are doing to regulate and improve quality of higher education in their off campus centres.

According to a case study of British Open University the university sets up study centres for open and distance learning programmes that were based in local colleges, schools or other educational establishments. These centres are opened on weekdays, evenings and sometimes on Saturdays as well. They provide facilities for students to meet with one another for discussions and mutual help for individuals and group discussions with a tutor counsellors and course tutors.

In those centres most students preferred to take part in their learning together to avoid the sense of isolation associated with correspondence students. Later this centres started to serve as a base for face to face tuition and were upgraded to provide a range of resources, most commonly a television, radio tapes of foundation courses, broadcasts and replaying facilities, reference materials, a common room and refreshments for teaching staff, a notice board on Open University events, internal advertisements and messages.

In Kenya both public and private universities that were initially established in main urban centres have expanded their operations to rural areas a phenomenon that needs to be investigated.

Higher education is no longer a luxury it is essential to national social and economic development. In the 1990s funding of post-secondary education in 
Kenya became a problem and until then the funding of tertiary education in general and that of university in particular does not seem to be areas of priority for governments and donor funding. The students who for one reason or another may not be able to raise the fees should seek bursary or loans from the Higher Education Loans Board while institutions are expected to sustain their operations. Most universities have resulted to augmenting their financial base by generating the needed income locally. Many universities do so by offering extension studies through off campus centres which often boost their enrolments. However, the sudden increase in number of universities and their satellite campuses, proliferation of programmes and the unprecedented increase in student enrolments in these centres have not matched the infrastructure and human resource base needed to support the ever increasing demand for higher education. In addition there are concerns about their operations at a time when calls for enhancing quality of higher education in many African countries are evident.

This study describes the phenomenon of expansion of university education in Kenya in relation to demand, examines the implications of expansion of access in higher education to quality of university education and propose a model that can guide higher education development.

\section{$2 \quad$ Methodology}

The study adopted ex post facto design. Two public universities and one private university were purposively sampled. These are among the pioneers in establishing off campus study centres, especially in rural set up far from the capital city. A purposive sample of administrative and teaching staff and students from these universities was obtained. Data were collected using indepth interviews, focus group discussion and an observation schedule which were designed to collect information on various aspects of the study centres. The in-depth interviews provided opportunity to collect detailed data that were validated to cover the study objectives and compare the respondents' opinions about study centres. Focused group discussion with students provided insights into some aspects that staff underrated but had significant impact on students' operations. The observation schedule helped to provide information especially on physical infrastructure to validate responses from the interviews. Secondary information provided vital information on relevant themes in comparing universities in Kenya regionally and international. 


\section{Phenomenal Growth of University Education}

In Kenya with virtual achievement of universal primary education and expansion of secondary education the higher education sub-sector equally requires expansion. In any case sustained economic growth is very much dependent on generation of middle and high level manpower. In the past, access to education in Kenya has been wider at primary, medium at secondary and narrow at the tertiary level portraying an open cone shape against the demand for highly trained human resource for sustainable social and economic development. Hence, public private partnership is being encouraged in provision of higher education through variety of incentives including tax breaks on educational materials and bursary support for private and public universities. In contrast with previous practice, universities are permitted to expand enrolments or open up new campuses after it is evident they have capacity to accommodate increased student numbers (Mwiria et al., 2007).

More importantly future expansion of higher education will be expected to take into consideration regional representation and variety of Kenya's natural resource base in relation to variety of courses to tap the potential of such diversity. Mwiria et al. noted that day universities will also be promoted so that socially and economically disadvantaged groups will have greater opportunities to enrol. The Republic of Kenya Report on Totally Integrated Quality Education (2000) observed that private universities have come to play a critical role in taking a large number of students who qualify to attend public universities but are unable to do so because of the limited number of vacancies available in public universities.

Recently the Kenya government promised changes in higher education and appointed a team of experts to review the required changes. The team reported six areas for reforms including: governance and management structures, quality and relevance, expansion and integration, access and equity, finance and financial management, community service and engagement with society. The target was integrating the increasing number of private institutions with more established public ones and putting in place appropriate mechanisms to support private-sector participation.

Access to university education has also been enhanced by the introduction of bridging courses. These programmes provide remedial instructions in Mathematics, Science, Languages and other critical subjects to help these students gain access to mainstream university system. Many colleges and universities in Kenya offer certificates and diploma courses especially to professionals in various fields enabling them to enrol for degree courses. According to Schuller (1991) increased access entails making education available to a greater number of students from a range of social economic 
backgrounds, through admission criteria, course organization and credit transfers.

In Kenya universities have enhanced access to higher education by locating campuses near the target populations. For instance JKUAT runs its course through various tertiary institutions under supervision of the main campus. University of Nairobi's college of Extra-Mural Studies has campuses in Mombasa, Kisumu, Kakamega, Nyeri, Meru, Nakuru, Garrissa, and Kisii. Kenyatta University had regional centres in all former provincial headquarters to manage its distance programmes in some of which have been upgraded to regional campuses that are fully operational in main urban centres like Nairobi city centre, Mombasa, Nakuru, Nyeri, Kitui and Kericho. Similarly universities located far from urban centres like Egerton University and Moi University have been compelled to set up campuses in main towns including Nairobi, Nakuru, Eldoret, Nyeri and Mombasa. Among the private universities Catholic University of East Africa with the main campus in Nairobi has established campuses in Mombasa Eldoret and Kakamega, while Mt Kenya University has campuses at Nairobi, Nakuru, and Mombasa among others.

In Britain a case study of British Open University centres revealed that limitations of rooms and the actual physical conditions varied enormously and made the establishment of a welcoming atmosphere difficulty. Condition of rooms was not conducive especially to the learners with special needs and the elderly, distractions from external noise was evident and location of the building whether in sparsely or densely populated area determined the potential attendance. Also availability and pattern of public transport as those with frequent service to major catchment areas had better chance of success. When students develop a sense of identity regarding the centre as theirs, it becomes a social as well as academic meeting place. It was observed that extra-curricular activities plaid a critical role in the most active and sufficiently attended centres. In addition a great deal of success depends on local tutor counsellors' ability to organize activities and resolve problems as they arise in collaboration with the part-time lecturers the students meet in the course of their study. In Nigeria in a span of ten years the extension undergraduate programmes increased from 35 to 900 and post graduate from zero to 35 . The increased enrolment posed a challenge for the respective institutions resulting to limited monitoring and the consequent insufficient or decrepit human and physical resources raising the issue of quality where most of such programmes are viewed as money spinning entrepreneurial initiatives (Ali, 1996).

In the Democratic Republic of Congo, like many developing countries higher education faces the challenge of responding to increasing demand while attempting to provide a quality education "The current situation is extremely difficult. Most universities, public and private, lack the necessary funds to provide basic educational infrastructure sufficiently spacious classrooms, 
laboratories, equipped teaching hospitals, libraries, computers, and Internet access (World Bank $(2000,18)$ ". In Kenya the case may be slightly better. However, most of the researches concentrates on the short comings and fails to highlight the achievements as evident in the move from centralized higher education towards decentralised provision of higher education in detached remote areas.

\section{$4 \quad$ Findings}

The study findings are organized in terms of expanding access; covering the main input indicators of universities. These include programmes, number of institutions, enrolment at various levels, faculty in terms of staff and resources available. Constraints mainly focused on overstretched staff and facilities and their implications on output while prospects focused on the benefits that have accrued from the study centres to various stakeholders and the pivotal role of ICT in their success.

\subsection{Expansion of Access to University Education}

Universities have increased in number. In the 1990s the number of both public and private universities increased from 10 to 50 in 2013. Most universities had witnessed growth by way of expanding their size to accommodate more students as well as opening new premises to enable them reach out to students in urban and remote areas nationally and in neighbouring countries. According to the Commission for University Education (2014) Chartered public universities in Kenya were 22 with 9 constituent colleges some of which have been upgraded to fully fledged universities, 17 private universities with 5 constituent colleges and 13 with letters of interim authority. The commission further encouraged foreign universities to apply for authority to collaborate with local universities.

All the universities in the study had opened multiple campuses in Nairobi and other main urban centres in Kenya with some operating campuses in neighbouring countries. However, the effort to enhance access has been experiencing challenges in form of teaching facilities and physical infrastructure which have been noted to be wanting. Some centres have only lecture halls with no libraries or laboratories. Also the opening of campuses has not eased congestion in main campuses. In a related study by World Bank (2000), expansion of higher education had produced many consequences. Many institutions had grown in size transforming themselves into mega universities; new types of institutions had been born with new providers entering the higher 
education sector and a range of vocational professional institutions to complement the traditional universities.

The study found that the centres established by various universities were offering undergraduate and postgraduate programmes. Undergraduate courses cover Diploma and Bachelor courses while postgraduate courses cover postgraduate diploma, masters and $\mathrm{PhD}$ programmes in public universities. The administrators were quick to report that the undergraduate programmes had high enrolments as compared to post graduate programmes. In view of one of the administrators in extension studies; Increased enrolment in undergraduate level can be attributed to " the demand for higher education in the country especially because higher education is a major component in acquiring a good job in this country" In addition majority of the students are straight from secondary schools where increasing numbers have been witnessed in the recent years especially with the launch of Free Primary Education followed by the Free Tuition Secondary Education and the next obvious level for them is university education especially if they are qualified. Even with the established campuses it was observed that output in research still remained low. Very few Doctoral students have been enrolled in these campuses, an indication that universities still have low output in research which is a key ingredient for social economic development of the region. Cleote, Bailey and Maassen (2011) established that research output in African universities is low owing to the number of publications and few graduates with Doctoral degrees.

On the same note an increasing number of working class students were observed. According to one of the academic staff:

Among the working class there seems to be a major trend for acquiring education - at whatever level - and many Kenyans especially adults are going back to school even if they begin from Certificate or diploma level to ensure they have higher education especially those who missed the opportunity earlier due to limited access. Since majority of Kenyans had left education after the secondary cycle in the 8-4-4 system or A- level for those in the former system. Consequently undergraduate education programmes seem to pick quite first at the centres in rural set ups.

Majority of students were enrolled in diploma and first degree courses as opposed to post graduate studies. Levy (2015) established that many countries are struggling to guarantee access to predominantly younger population.

The courses are offered on a flexible mode of delivery: Saturday only, evening, one day a week, two days a week, school based which runs during the regular school holidays targeting teachers, The e-learning programmes are in process to reach out for learners who are not able to access the study centres but can participate in interactive sessions through various forms of media. It is 
notable that mature learners who are working are the majority especially in the evening and Saturdays' only courses.

In view of student enrolments it emerged that enrolments had significantly increased in extension as compared to full time courses in the main campus especially in private universities. For public universities centres started with low numbers and experienced gradual growth with time as students still valued admission to main campuses as compared to satellite campuses. Students especially secondary school leavers viewed admission to main campuses which are mainly located cities to be more prestigious as they were reputable and endowed with more resources, better human resource, infrastructure including hostels and libraries and recreation facilities. Agarwal (2015) argues that even with differences much lower there is competition among students for top institutions based on reputation and perceptions.

With regard to facilities administrators acknowledged that some of the satellite campuses had received overwhelming numbers putting strain to the limited facilities. For the administrative staff they opine that initially it was very challenging for registry staff to move to the off campuses and effectively offer this service due to the constraint of distance, differences in sessions and students coming from interior regions were challenged often demanding an extension of registration period. Without on-site offices, any student who would miss the registration day, for whatever reason would travel to main campus to register. This contradicts the Commission for University Education (2014) guidelines in Kenya that campuses should provide students with services like sports facilities, counselling, indoor games, health unit, worship rooms and eating places. A study on Makerere in transition observed that massive increase in enrolment had not been accompanied with increased improved facilities. Notwithstanding, the pressure of work staff and faculty were grappling with (Nakanyike and Nansozi, 2003).

Among the key indicators of performance in higher education is graduation rates of students enrolled in different programs. In relation to retention of students they observed that among the reasons causing students to drop out; majority dropped out due financial related reasons, while a smaller number among the employed would abandon courses due to deployment to different parts of the country which was viewed as common with government employees, a few students would also discontinue their studies due to low capacity to engage academically resulting to low grades thereby failing to meet the institutional set standards, in other instances students would register but discontinue due to job demands that cannot allow them to fit in any of the provided modes especially those working for small private companies which do not provide leaves with pay and employees worked to late hours in the week and on weekends. However, it was observed that over 90\% complete their studies successfully. Agarwal (2015) called on universities to develop specific 
programs to guarantee not only access to students of diverse backgrounds but also success for every student, reducing failure and dropout rates without compromise to quality of degree awarded.

With reference to composition of students' study centres, outside the capital city Nairobi hosted mainly Kenyans from rural regions while the main campus centre had students from diverse nationalities ranging from the US, Spain, Nigeria, Ghana, Cameroon, DRC, Rwanda, Tanzania, Southern Sudan, Ethiopia and Eritrea among others.

The extension staffs were of the opinion that the management seeks to locate centres in premises usually church or college facilities preferably within a town or its environs with ample space, conference halls/classrooms as well as residential facilities, (accommodation and meals) for both teachers and students, rooms that can be used for Library/IT laboratories, and offices in future. Preferably a centre with potential for growth in terms of physical development and reliable transport hired on contract.

On establishment library facilities were gradually developed by utilizing available rooms which are modified to suit the purpose. Volumes of text books and other related library resources are availed guided by the programmes on offer and/or courses on offer at the centre. Other resources include DVD's, on line journals and e books. For teaching staff as many as 15 books on 'one month loan' are availed. Extension students access all the above resources as well. To ease the difficulties in handling their course assignments the main campus library extends special loans to the extension students who can borrow books for a whole month and can renew books on line or just through a text message. However, the part time instructors expressed concern that sometimes they have been forced to obtain relevant course materials from the main campus library, which they provide for students to photocopy to get going. This is common with first groups in various programs whereby key reference materials are missing from the off campus centres' resources rooms. This is contrary to conditions in many developing countries where "in general students have no textbooks, and professors must dictate their notes or copy them onto a blackboard. The majority of schools have no library, no telephone, and not a single computer that students can use". According to World Bank (2000), schools in the DRC share a number of serious problems. The DRC as a whole lacked sufficient resources to provide adequate support to faculty.

As concerns the faculty fulltime staffs mainly serve in the main campus. However, depending on the workload, they are also deployed to the out-of campus centres. The ratio of fulltime to part time academic staff was found to be at $1 / 3$ as reported by administrative staff;

We have more part teachers serving in the off campus centres and some of the part time teachers also get teaching assignments in the main campus. Regular faculty members are also assigned extension classes - although the 
number willing to teach evening and school based is small as part of their regular workload. However, if a regular lecturer has overload by teaching an extension class, he/she gets paid for the extra course (s) taught. The extension staff were of the opinion that many faculty members were sceptical and unwilling to teach a course in the study centres. Some centres were operating through the presence of part time teachers only. It was equally difficult to 'convince' officers from accounts and registry to go to these centres to collect money and carry out registration in the study centres respectively as they felt overstretched. These responsibilities were left solely on the extension office which had few staff members to cope with the needs of growing number of students.

From the foregoing the issue of covering the required course hours is not guaranteed specially with the part time teachers mainly drawn from regular staff in other universities. From the students the study established that "punctuality is also not guaranteed as well and as a result students have often complained to the management in this regard". This raises issues of whether the content was adequately covered and whether the students have been exposed to required guidance. There were cases where courses had been rescheduled due to unavailability of teachers in some technical courses due to inability of parttime lecturers to cope with the demands of their regular engagement as retaliated by most staff. However, it was noted that the inadequate number of lecturers in technical and advanced level was a country wide problem and to some extent international.

\subsection{Challenges}

Increasing student enrolment has overstretched the capacities of libraries, lecture theatres, laboratories and the faculty. In public universities it has been observed that library capacities serve even five times more than the student population they were meant to serve. It is in the light of this that libraries at Kenyatta and Nairobi Universities have expanded with computer units that allow staff and students remote access to digital resources. Among the recent developments Kenyatta University established her "Post Modern" library and a "Mute Court" to match increased enrolments and variety of programmes providing the state of the art services to both local and international students.

Extension studies being a new phenomenon faced challenges ranging from staff, infrastructure, institutional support, students community acceptance and course material development. In regard to faculty in one private university coming from an initially donor funded and church sponsored programmes the faculty members were used to the comfort zone and were not willing to welcome the idea of people learning outside the perimeter fence of the main 
campus and they were hostile towards extension studies. This hostility became a real threat to development in extension studies centres. At some point "some HODs were highly suspicious and were unwilling to assign their fulltime teachers to extension studies neither giving the way forward". More often courses were delayed as they looked for part time teachers, asked them to fill application forms and requested the institutional management to process their files urgently. In many cases they depended on marginally qualified lecturers who were readily available.

The extension staffs were emphatic on challenges related to condition of lecture rooms "in some cases we have had to request for renovations to be carried out in or order for the rooms to suit the teaching learning requirement/environment in terms of ventilations, opening of doors and windows that are in many cases inadequate. Many times the staff had to contend with complete absence or inadequate basic teaching/learning components like white boards/flip charts and projectors. However, this is not a problem of campuses in Kenya alone. For instance in South America some institutions have had to stretch their organizational boundaries, giving birth to "mega-universities" such as the National University of Mexico and the University of Buenos Aires in Argentina, each of which has an enrolment of more than 200,000 students. In many instances expansion, both public and private, has been "unbridled, unplanned, and often chaotic. The resultsdeterioration in average quality, continuing interregional, inter-country, and intra-country inequities, and increased for-profit provision of higher education could all have serious consequences (World Bank 2000, pg. 27)". In a related discussion Lane and Kinster (2015) established that 18\% of institutions had rented their campus space and that in some cases multiple institutions could rent similar space in same building giving students academic options to choose from. However, this served as transitional phase as institutions planned to build their own campus.

Learners have also had their share of challenges. Many learners expressed concern that quite often they feel orphaned as the teachers are too far and inaccessible at times when they need their assistance to meet their individual needs. They also felt detached from the institutional warmth and lack sense of belonging. According to the coordinator of extension studies in one of the universities "some ensure they visit the main campus before their graduation to have a feel of the institution they claim to belong to". They also feel isolated from their fellow students when off session and do not have the advantage of group discussions. Many students lived in rural set ups where internet facilities are not accessible this complicates their effort to access relevant learning resources in form of e-books or journal articles especially in centres that have no adequately equipped libraries. Lack of infrastructure frequently caused 
students to study humanities and arts resulting to educated unemployment (Levy, 2015).

This amounts to long duration in completion of courses especially research projects where they lose contacts with lecturers and other students necessitating delays. In Botswana the thinking behind the study centres was to set up well lit and comfortable place to study away from homes where students were distracted from their studies. The centres were aimed at making students feel they are members of a larger community especially with the presence of tutors to respond to their problems. This encouraged students to continue with their studies as compared to learning through correspondence.

Initially the centres were managed from the main campus with the implication that without support staff the centres remained closed for long periods with no one to handle day -to-day correspondences between students and the institution and many questions remained un answered slowing down students' progress. However, with increased enrolment the centres have had to engage support staff to manage and facilitate operations in relation to staff and student matters.

\subsection{Prospects of Study Centres}

The centres provide face to face tuition which most students preferred so as to take part of their learning together, engage in discussions, and consult lecturers gaining a sense of belonging. They however, provided golden opportunities for working students to pursue educational aspirations as they work especially in the case of courses offered in the evenings, Saturdays, school based, and one day a week "providing education at our door step". They have also enhanced development in the community as highlighted by extension staff:

The centres mainly engage both teaching and support staff locally and provide learning resources for the local community. The centres' library remains open for public at affordable rates. They provide a golden opportunity for many rural community members who had missed out on higher education for a long period because they were not able to move to mainstream universities mainly located in Nairobi and other major towns. They have also facilitated the physical development of these regions where the centres are located.

On a similar note one respondent reiterated that "the campus has grown from a consistent enrolment of about 100 students to currently over 600 in our study centres". The institution has made an impact in building the human resource capacity in Kenya, Africa and the world through its alumni more so among the rural groups that have been marginalized in access to higher education. Through the centres the institution has participated in creation of employment 
through engagement of more faculty and support staff in phase of increasing number of students. The institution has also gained popularity in the regions that host the centres an important step in boosting the institution's financial base

As pertains to the role of ICT in development of learning centres, the recent advancement in technology offers more options for delivery and receiving education over geographical distance paving way for more opportunities in study centres without necessarily spending more on physical facilities. Staff in extension study acknowledged that management of students/staff records was made easier and coordination of staff/students activities through emails and mobile phones has gone further to ensure effective flow of information. They further reported that the institution have email accounts for all students where they can instantly access information on registration and any other information relating to their courses. The role of ICT in Teaching and learning cannot be under estimated "there are already attempts in applying interactive modes of teaching and learning where some lecturers use the e learning platform in the area of content, delivery, issuing and delivery of assignments making extension studies more convenient". Mobile phones information transfer in teaching and learning between lecturers and students is also another mode that is currently being used. The staff further observed that some lecturers are using projectors for power point presentations and effort was being directed to exploring e learning platform to cater for students in more diverse regions. It was on this line that Kenyatta University opened the Digital School where use of multimedia is making learning interesting and flexible for working students and those in remote locations.

It was further noted that advances in information technology, meanwhile, have made this ever-increasing volume of knowledge more accessible, effective, and powerful. The Internet, in particular, means that more knowledge than ever is in circulation and for those who have the skills to use it have access to valuable resource locally and at international level.

\section{Conclusion}

Evidently many Kenyan universities have established study centres or campuses in main urban centres. These centres as a more widespread phenomenon now in Kenya have been faced with various challenges, they may not have achieved the required in terms of material and human resources, however, they have provided a platform for higher education access especially for initially marginalized groups. These centres have enormous potential to provide higher education programmes at various levels. The centres have 
created economic hubs where business community have also set up businesses to cater to growing demand for goods and services among students and staff creating employment opportunities. To achieve their vision Universities should explore alternative funding, integration of better planning and efficient management to promote access and improved quality of higher education for sustainable development of the nation, the region, and beyond.

\section{Recommendations}

In view of foregoing the study recommended more varied modes of funding higher education through partnerships with government and non-governmental organizations to enhance more access especially to the disadvantaged groups. More investment is critical especially in ICT which forms the pillar on which future successful higher education lays and especially for the study centres which are getting overwhelmed in terms of physical facilities in face of limited donor funding. Internet based technology is the vehicle to reach a wider range of students in remote locations as well as the urban poor in low income areas. Accreditation of institutional facilities and programmes by respective national bodies like Commission for University Education in Kenya will play a vital role in effort to improve the quality while expanding access which is equally important in promoting social and economic development of this country. This must be complemented with establishment of quality indicators and instruments to measure them at institutional level that are continually reviewed and publicized in all functional departments.

To succeed in opening access to meet the ever increasing demand partnerships at local and international levels are critical in mobilizing resources needed for transformation of higher education. Such partnerships entail cooperation and collaboration of state institutions, universities, students, private sector organizations, professional bodies, communities and civil society and individual experts. This will help universities to consider basic requirements in their off campus centres like physical infrastructure, library facilities, lecture rooms and faculty members matching launched programmes. They can also explore possibilities of partnering with existing institutions and local communities. In such environment faculty and students will be able to engage in teaching and learning, research and community service. Essentially students will be able to graduate in set timelines encouraging more students to enrol. This is will definitely lead to individual students, benefits, employer satisfaction and the general social, economic and political development at national, regional and global level leveraged on human capital and innovations to solve problems affecting modern society. There is need for a coherent model to enhance higher education development creating frontiers of knowledge, 
research and community service as compared to the current haphazard development where many have opened campuses as quick fixes for generating extra income as illustrated in the proposed model Figure 1.

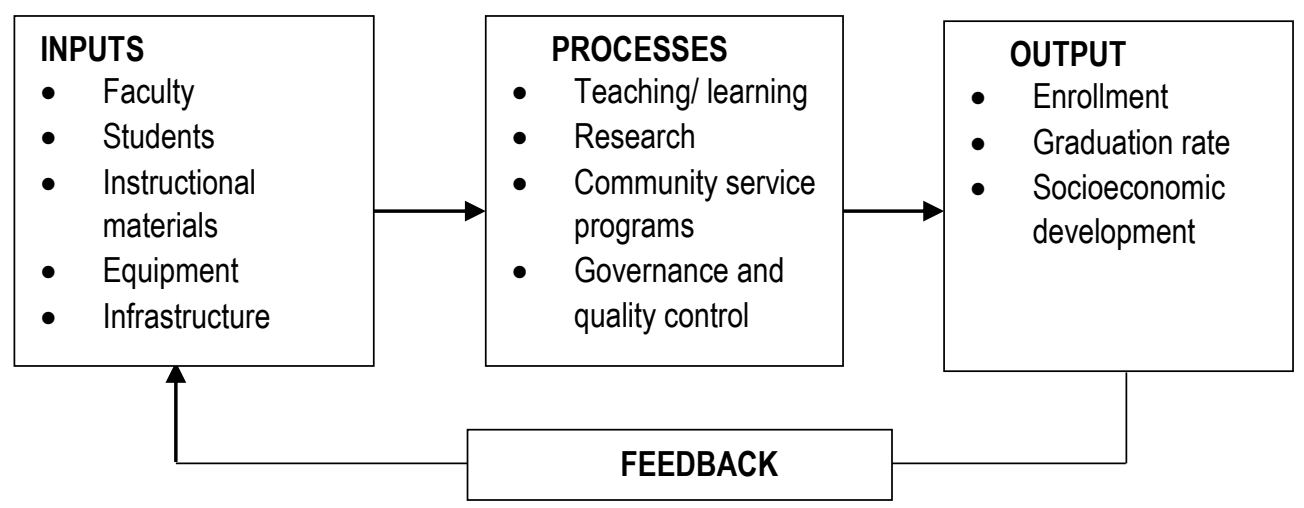

Figure1: Model for improving Quality in Higher Education

A critical examination of trends in higher education development reveals that it is also possible for institutions to cooperate with others in specific regions whereby they can share human, physical capital, knowledge and ideas. There is need to move from competition to cooperation forming learning centres where computer laboratories and libraries are open to all students.

\section{References}

Ali, A. (2012). Academic Standards of Extension and Satellite Programmes of Nigerian Universities: Management and Control. Nsu'kka: University of Nigeria (http://www.col.org/forum/PCFpapers/ali2.pdf).Retrieved February, 2012.

Agarwal, P. (5015). Next Two Decades of Higher Education: A Developing Countries Perspective. Symposium Essays. HE in Developing Countries. Pdf Retrieved March, 2015.

Bahemuka, J. M. and Brockington J. L. (2001). East Africa in Transition: Communities, Cultures and Change. Nairobi: ACTION.

Cleote, N., Bailey, T. and Maassen, P. (2011). Universities and Economic Development in Africa. CHET (www.chet.org.za). Retrieved January, 2013.

Commission for University Education (2014). Universities Authorized to operate in Kenya at www.cue.or.ke re.

Handbook of Research for Educational Communication and Technology: History of Distance Education, http.//www.aect.org/edtch/ed1/13/13-02html. 
Lane, J and Kinster, K. (2015). Models of International Branch Campus Ownership. IHEpaper.pdf.

Levy, D. C. (2015). Do Not Fall for It. Albany University. New York. Higher Education Quality. Pdf. Retrieved January 2015.

Mwiria, K. Njugunah, N., Charles, N., Douglas, O., Violet, W. and Daniel, W., (2007). Public and Private Universities in Kenya. Nairobi: East African Educational Publishers.

Nakanyike, B. and Nansozi, K. (2003). Makerere University in Transition (1993-2000). Kampala: Fountain Publishers.

Republic of Kenya (2000). Totally Integrated Quality Education. Nairobi: Government Publisher.

Schuller, T. (1991). The Future of Higher Education. Buckingham: Open University press.

World Bank. 2000 Higher Education in Developing Countries: Peril and Promise. The Task Force on Higher Education and Society. Washington, D.C. 